\title{
Vitamin D toxicity in a pediatric toxicological referral center; a cross-sectional study from Iran
}

\author{
Fariba Farnaghi ${ }^{1}$, Hossein Hassanian-Moghaddam ${ }^{2,3}$, Nasim Zamani ${ }^{2,3}$, Narges Gholami ${ }^{1 *}$, Latif Gachkar ${ }^{4}$ and \\ Maryam Hosseini Yazdi ${ }^{5}$
}

\begin{abstract}
Background: Vitamin D is an essential element for body health with its supplements generally administered to prevent vitamin $D$ deficiency. Since these supplements are available in domestic settings, vitamin D toxicity may happen in children.

Methods: All children younger than 12 years who presented to the pediatric emergency department of Loghman Hakim Hospital, Tehran, Iran with history of ingestion of more than $1500 \mathrm{IU} /$ day of vitamin D supplements were enrolled. Patients' demographic data, on-presentation signs and symptoms, laboratory findings, treatments given, and outcome were evaluated.

Result: Fifteen patients presented during the study period. Their mean age was $46.53 \pm 10.14$ months and 12 (80\%) were girls. All of them had unintentionally ingested vitamin D. Mean ingested dose was $406700.7 \pm 227400.1 \mathrm{IU}$. In eight patients (53.3\%), 25 hydroxy vitamin D level was more than $100 \mathrm{ng} / \mathrm{mL}$. One patient experienced hypercalcemia while all of them were asymptomatic and discharged without complications. There was no significant difference between patients with and without high levels of $25 \mathrm{OH}$ vitamin D regarding lab tests, toxicity course, and outcome.

Conclusions: It seems that acute vitamin D toxicity is a benign condition in our pediatric population which may be due to high prevalence of vitamin D deficiency in Iran.
\end{abstract}

Keywords: Vitamin D, Toxicity, Pediatrics

\section{Background}

Vitamin $\mathrm{D}$ is a fat-soluble pro-hormone primarily synthesized in skin by sun-light exposure [1,2]. Dairy products, fish, and mushrooms may also contain small amounts of vitamin D [3, 4].This vitamin has a crucial role in the health of the musculoskeletal system.

\footnotetext{
*Correspondence: Nargesgholami724@yahoo.com

'Departments of pediatrics, Loghman Hakim Hospital, School of Medicine, Shahid Beheshti University of Medical Sciences, South Kargar St, Makhsos St, Tehran, Iran

Full list of author information is available at the end of the article
}

Furthermore, vitamin D has beneficial effects on cardiovascular, respiratory, and immune systems [4-12].

Due to issues including heavy clothing, air pollution, reduced exposure to direct sunlight, inadequate nutrition, and lack of access to vitamin D-rich food especially among children, vitamin $\mathrm{D}$ deficiency is a common health problem in our country [13-15]. Thus, consumption of vitamin D containing supplements is encouraged in Iran during the recent years making them more available for unintentional poisonings in children although the frequency of poisoning with these supplements is still low compared to other poisonings in them

(C) The Author(s). 2020 Open Access This article is licensed under a Creative Commons Attribution 4.0 International License, which permits use, sharing, adaptation, distribution and reproduction in any medium or format, as long as you give appropriate credit to the original author(s) and the source, provide a link to the Creative Commons licence, and indicate if changes were made. The images or other third party material in this article are included in the article's Creative Commons. licence, unless indicated otherwise in a credit line to the material. If material is not included in the article's Creative Commons licence and your intended use is not permitted by statutory regulation or exceeds the permitted use, you will need to obtain permission directly from the copyright holder. To view a copy of this licence, visit http://creativecommons.org/licenses/by/4.0/ The Creative Commons Public Domain Dedication waiver (http://creativecommons.org/publicdomain/zero/1.0/) applies to the data made available in this article, unless otherwise stated in a credit line to the data. 
[16-20]. Vitamin D toxicity may also happen as a result of inappropriate dose administration by physicians or errors in manufacturing or unlicensed vitamin D preparations [21-25].

Daily recommended dose of vitamin D supplements is reported to be $400 \mathrm{IU}$ in infants, $600 \mathrm{IU}$ in people younger than 70 years of age, and $800 \mathrm{IU}$ in people over 70 [26-29]. Since studies in this regard are lacking in children, we aimed to assess all children with vitamin D toxicity referring to a tertiary referral center of toxicology during a year.

\section{Methods}

In a retrospective descriptive cross-sectional study performed in Loghman Hakim Hospital between March 21st, 2018 and March 20th, 2019, all children younger than 12 years who presented to the pediatric emergency department with the history of vitamin D supplements ingestionof more than $1500 \mathrm{IU}$ in a single occasion were enrolled in this study. Written informed consents were taken from the patients' parents before case enrolment. After taking history and physical examination, blood tests were performed six hours post admission.

All demographic data (age, sex, weight, amount of vitamin $\mathrm{D}$ ingested), vital signs(blood pressure, heart rate, dehydration signs), symptoms on presentation (nausea, vomiting, abdominal pain, loss of appetite, irritation, headache, constipation, polyuria, polydipsia, fever, and growth retardation), laboratory findings (25 $\mathrm{OH}$ vitamin $\mathrm{D}$, serum calcium, phosphate, alkaline phosphatase, urea, creatinine, urine $\mathrm{Ca} / \mathrm{Cr}$ ), treatments given (close observation, hydration, steroid, bisphosphonate), and outcome (recovery, death) were recorded and analyzed using statistical package for social sciences (SPSS) version 18.

This study was approved by the ethics committee of Shahid Beheshti University of Medical Sciences (IR.SBMU.RETECH.REC.1397.1216).

\section{Results}

Fifteen patients presented during the study period. Their mean age was $46.53 \pm 10.14$ months (range; 24 to 60 months). Twelve patients $(80 \%)$ were girls (male/female ratio was 1:4).Patients were referred $2.5 \pm 1.6 \mathrm{~h}$ (range; 0.5 to $5 \mathrm{~h}$ ) after the vitamin D supplement ingestion. had all ingested vitamin D supplements unintentionally and accidentally (oral 50000-IU vitamin D pearls). Mean ingested dose was $8.13 \pm 4.54$ pearls (range; 3 to 18 pearls) or $406700.7 \pm$ 227400.1 IU (range;150000 to 900000 IU). One patient had serum calcium level of $12.5 \mathrm{mg} / \mathrm{dL}$. She had ingested500000 IU vitamin D. After six hours of hydration, her serum calcium was normal. Patients' information is mentioned in Table 1.
Table 1 Vitamin D dose and biochemical features in individual patients

\begin{tabular}{|c|c|c|c|}
\hline Cases & $\begin{array}{l}\text { Vit D dose } \\
(\times 50000 \mathrm{IU})\end{array}$ & $\mathrm{Ca}(\mathrm{mg} / \mathrm{dl})$ & $25-\mathrm{OH}$ vit $\mathrm{D}(\mathrm{ng} / \mathrm{ml})$ \\
\hline 1 & 10 & 12.5 & 10 \\
\hline 2 & 3 & 10.5 & 35.5 \\
\hline 3 & 4 & 9.5 & 48.3 \\
\hline 4 & 5 & 8.7 & 55 \\
\hline 5 & 8 & 10.2 & 56 \\
\hline 6 & 4 & 10.5 & 65 \\
\hline 7 & 8 & 10.5 & 97.3 \\
\hline 8 & 17 & 8.9 & 102 \\
\hline 9 & 3 & 10.4 & 104 \\
\hline 10 & 6 & 9.7 & 107 \\
\hline 11 & 10 & 10.4 & 111 \\
\hline 12 & 7 & 10.1 & 120 \\
\hline 13 & 9 & 10.2 & 120 \\
\hline 14 & 18 & 9.8 & 138 \\
\hline 15 & 10 & 9.3 & 500 \\
\hline
\end{tabular}

Eight (53.3\%) cases had $25 \mathrm{OH}$ vitamin D levels more than $100 \mathrm{ng} / \mathrm{mL}$. Mean serum 25-OH vitamin D was $111.3 \pm 113.6$ (range; $10 \mathrm{ng} / \mathrm{mL}$ to $500 \mathrm{ng} / \mathrm{mL}$ ). There was no significant difference between variables in patient with and without high level of $25-\mathrm{OH}$ vitamin $\mathrm{D}$. The most important data is mentioned in Tables 2 and 3 .

None of them had signs and symptoms of vitamin D intoxication; $46.7 \%$ were observed for eight hours and received activated charcoal. Additionally, 53.3\% were hospitalized and treated by activated charcoal and fluid therapy. All cases were discharged without any complications. All patients were taking vitamin D regularly. We recommended them to discontinue consumption of vitamin D supplements, keep lowcalcium and vitamin $\mathrm{D}$ diet, take more liquid for at least one month, and recheck $25-\mathrm{OH}$ vitamin D levels. Unfortunately, most of the patients did not refer for follow-up checkups.

\section{Discussion}

A definite amount of vitamin D ingestion to cause toxicity has not been elucidated. Although maximum tolerable ingested dose is various in different age groups, maximum tolerable and safe dose of vitamin $D$ is $1000 \mathrm{IU} /$ day in infants younger than 6 months, $1500 \mathrm{IU} /$ day in children older than 6 months, and $10000 \mathrm{IU} /$ day in adults [27, 28, 30-33]. 
Table 2 Lab parameter features in patients (Mean \pm SD)

\begin{tabular}{|c|c|c|c|c|c|c|c|c|}
\hline Group & & $\begin{array}{l}25-\mathrm{OH} \text { vit D } \\
(\mathrm{ng} / \mathrm{ml})\end{array}$ & $\begin{array}{l}\mathrm{Ca} \\
(\mathrm{mg} / \mathrm{dl})\end{array}$ & $\begin{array}{l}P \\
(\mathrm{mg} / \mathrm{dl})\end{array}$ & $\begin{array}{l}\text { ALK-P } \\
(\mathrm{U} / \mathrm{L})\end{array}$ & $\begin{array}{l}\mathrm{Cr} \\
(\mathrm{mg} / \mathrm{dl})\end{array}$ & $\begin{array}{l}\text { Urea } \\
(\mathrm{mg} / \mathrm{dl})\end{array}$ & $\begin{array}{l}\mathrm{Ca} / \mathrm{Cr} \\
\text { Urine random }\end{array}$ \\
\hline \multirow[t]{2}{*}{$\begin{array}{l}25-\mathrm{OH} \text { vit D } \\
<100 \mathrm{ng} / \mathrm{ml}\end{array}$} & $\begin{array}{l}\text { Mean } \\
N=7\end{array}$ & 52.4 & 10.3 & 4.8 & 478.0 & 0.4 & 26.7 & 0.2 \\
\hline & Std. Deviation & 26.7 & 1.2 & 0.7 & 31.1 & 0.3 & 10.8 & 0.2 \\
\hline \multirow[t]{2}{*}{$\begin{array}{l}25-\mathrm{OH} \text { vit D } \\
>100 \mathrm{ng} / \mathrm{ml}\end{array}$} & $\begin{array}{l}\text { Mean } \\
N=8\end{array}$ & 162.9 & 9.8 & 4.7 & 546.0 & 0.6 & 23.7 & 0.1 \\
\hline & Std. Deviation & 136.7 & 0.5 & 0.6 & 38.5 & 0.1 & 6.1 & 0.2 \\
\hline \multirow[t]{2}{*}{ Total } & $\begin{array}{l}\text { Mean } \\
N=15\end{array}$ & 111.3 & 10.1 & 4.7 & 526.6 & 0.6 & 24.6 & 0.2 \\
\hline & Std. Deviation & 113.6 & 0.9 & 0.6 & 47.4 & 0.2 & 7.3 & 0.2 \\
\hline
\end{tabular}

Vitamin D concentration is measured by 25- hydroxy vitamin D level because it has longer half-life compared to $1,25 \mathrm{OH}$ vitamin $\mathrm{D}[27,34]$. Although there are different ranges of 25- OH vitamin D levels in several studies, the optimal level of $25-\mathrm{OH}$ vitamin D is $30-$ $100 \mathrm{ng} / \mathrm{mL}$. Based on the normal range provided by the kit manufacturer, $25-\mathrm{OH}$ vitamin $\mathrm{D}$ less than $10 \mathrm{ng} / \mathrm{mL}$ is deficient, while levels $11-30 \mathrm{ng} / \mathrm{ml}, 31-100$, and over $100 \mathrm{ng} / \mathrm{mL}$ are insufficient, sufficient, and vitamin $\mathrm{D}$ toxicity, respectively [35].The most important laboratory findings in vitamin D toxicity are high levels of $25-\mathrm{OH}$ vitamin D and hypercalcemia [34].

Patients with vitamin D toxicity may be asymptomatic or have signs or symptoms including nausea, vomiting, dehydration, abdominal pain, loss of appetite, irritation, headache, constipation, polyuria, polydipsia, fever, and growth retardation. In fact, most of the patients' symptoms are compatible with high serum calcium level [32, 36]. Differences between symptoms and laboratory parameters in patients may be related to gastrointestinal absorption, vitamin $\mathrm{D}$ binding protein, vitamin $\mathrm{D}$ receptor (VDR), vitamin D storage, and diet [21, 32, 36]. All of our patients were asymptomatic and it might be due to the maximum tolerable intake dose differences in various groups and high prevalence of vit D deficiency among Iranian children [14, 32]. Also further studies are needed to be performed in this regard.
Vitamin D deficiency is estimated to be approximately $35 \%$ in boys and $65 \%$ in girls in Iranian pediatric population. Frequency of vitamin D insufficiency is reported to be $31 \%$. It shows that vitamin D deficiency is a critical health problem among Iranian children. Recently, the prevalence of vitamin D toxicity has increased because of more availability of its over-thecounter supplements $[37,38]$.

This study is one of the first ones about vitamin D toxicity in Iranian children. Although there are various studies in this regard worldwide, most of them have been performed on adults. It describes all cases of pediatric vitamin $\mathrm{D}$ toxicity that had referred to a major center for treatment of poisoned children in Tehran, Iran within a year.

All of our patients were between 24 and 60 months of age and had unintentionally ingested 50000-IU vitamin D pearls. In fact, D-pearls are small, soft gelatin capsules with 50000 IU of vitamin D3 in each capsule that may be attractive for children. Also, accidental poisoning in this age is more common. In the majority of studies, poisoning happens more frequently in boys, but in this study, poisoning was more common among girls $[39,40]$. This cannot be generalized to the whole population because our study is only a case series in one center during a year.

We observed all patients for eight hours in emergency room and received activated charcoal. Laboratory tests

Table 3 Demographic features in patients (Mean \pm SD)

\begin{tabular}{|c|c|c|c|c|c|c|}
\hline Group & & $\begin{array}{l}\text { AGE } \\
\text { (month) }\end{array}$ & Vit D dose $(\times 50000 \mathrm{IU})$ & $\begin{array}{l}\text { BP systolic } \\
(\mathrm{CmH} 2 \mathrm{O})\end{array}$ & $\begin{array}{l}\mathrm{HR} \\
\text { Beat/min }\end{array}$ & $\begin{array}{l}\text { Weight } \\
(\mathrm{Kg})\end{array}$ \\
\hline \multirow[t]{2}{*}{$\begin{array}{l}25-\mathrm{OH} \text { vit } \mathrm{D} \\
<100 \mathrm{ng} / \mathrm{ml}\end{array}$} & $\begin{array}{l}\text { Mean } \\
N=7\end{array}$ & 46.3 & 6.0 & 97.8 & 109.7 & 16.5 \\
\hline & Std. Deviation & 12.8 & 2.6 & 6.4 & 5.1 & 3.4 \\
\hline \multirow[t]{2}{*}{$\begin{array}{l}25-\mathrm{OH} \text { vit } \mathrm{D} \\
>100 \mathrm{ng} / \mathrm{ml}\end{array}$} & $\begin{array}{l}\text { Mean } \\
N=8\end{array}$ & 46.7 & 10.0 & 96.2 & 99.4 & 15.8 \\
\hline & Std. Deviation & 8.0 & 5.2 & 7.9 & 8.6 & 0.6 \\
\hline \multirow[t]{2}{*}{ Total } & $\begin{array}{l}\text { Mean } \\
N=15\end{array}$ & 46.5 & 8.1 & 97.0 & 104.2 & 16.1 \\
\hline & Std. Deviation & 10.1 & 4.5 & 7.0 & 8.8 & 2.3 \\
\hline
\end{tabular}


were checked six hours after vit $\mathrm{D}$ consumption. If they had hypercalcemia or $25-\mathrm{OH}$ vit D more than $100 \mathrm{ng} /$ $\mathrm{ml}$, they were hospitalized and treated by activated charcoal and fluid therapy. Their serum calcium was rechecked after four hours of rehydration.

Some studies have demonstrated higher frequencies of symptoms and hypercalcemia in their patients compared to ours reporting hypervitaminosis $\mathrm{D}$ in adults and a few children, whereas in this study more than half of our cases (53.3\%) had high levels of 25-OH vitamin D and just one had hypercalcemia without any symptoms who was hydrated. It may be due to high prevalence of vitamin D deficiency in Iranian children. On the other hand, vitamin D has long half-life because of its lipid solubility which leads to tendency for prolonged hypercalcemia. The absence of symptoms in our patients may be due to early laboratory parameters assessment mandating rechecking of the lab tests in consecutive hours post admission [19, 41-47].

One patient with hypercalcemia had $25-\mathrm{OH}$ vitamin D level of $10 \mathrm{ng} / \mathrm{ml}$; this might be due to the prozone or hook effect which is a known drawback in vitamin D measurement by Enzyme-linked Immunosorbent Assay (ELISA) method leading to falsely low vit D levels $[48,49]$.

We found only one study that had reported a patient with vitamin D intoxication in Iranian children. Faraht reported a 50-day-old girl in Imam Reza Hospital, Mashhad, Iran, with respiratory distress and hypotonia who had plasma creatinine of $1.4 \mathrm{mg} / \mathrm{dL}, \mathrm{BUN}$ of $11 \mathrm{mg} / \mathrm{dL}$, serum calcium level of $18.3 \mathrm{mg} / \mathrm{dL}$, and $25-\mathrm{OH}$ vitamin $\mathrm{D}$ of $75 \mathrm{ng} / \mathrm{mL}$ which were higher than normal range. It was due to the constant use of premature formula with high dose of vitamin D drop supplement (800 units /day) [50].

We had no access to the patients' previous vitamin D levels and did not know if they were previously vitamin D-deficient or not. This is probably the most important limitation of the current study. Although there is not any reliable data on vitamin D toxicity among Iranian children, Spiller et al. have reported there were 25397 human exposures to vitamin D in USA in 2000-2014. It explains that between 2005 and 2011, vitamin D toxicity increased $1600 \%$. There was $0.02 \%$ morbidity without mortality [51]. These results indicate that we need further researches in this field and vitamin D toxicity and vitamin D supplement intake should be more cautiously evaluated in children [45, 52-54].

\section{Conclusion}

Although vitamin $\mathrm{D}$ toxicity is a rare poisoning among children, it is a critical condition due to serum calcium disturbances. It seems that acute vitamin D toxicityis a benign condition and has a good prognosis in Iranian pediatric population maybe due to high prevalence of vitamin D deficiency in Iranian children. Due to insufficient and limited studies among children, we need more studies in this regard.

\section{Abbreviations}

Vit D: Vitamin D; $250 H$ vitamin D: $25-H y d r o x y$ vitamin D; IU: International Unit; BUN: Blood urea nitrogen; mg/dl: Milligrams per deciliter; ng/ ml: Nanograms per milliliter; ALK-P: Alkaline phosphatase; Ca: Calcium; P: Phosphor; HR: Heart Rate; BP: Blood Pressure; ELISA: Enzyme-linked Immunosorbent Assay

\section{Acknowledgements}

This study was supported by Toxicological Research Center, Loghman Hakim Hospital, Shahid Beheshti University of Medical Sciences, Tehran, Iran. Also we appreciate Dr Shahram Sabeti (Medical Laboratory Director, Loghman Hakim hospital, Shahid Beheshti University of Medical Sciences, Tehran, Iran).

\section{Authors' contributions}

NG: Conceptualization and search references. FF and HHM: Consultant. LG: Methodologist. MHY: Data collection and writing-review. NZ: Manuscript drafting and Editing. All authors have read and approved the manuscript.

\section{Funding}

Not applicable.

\section{Availability of data and materials}

The datasets used and analysed during the current study are available from the corresponding author on reasonable request.

\section{Ethics approval and consent to participate}

This study was approved by the ethics committee of Shahid Beheshti University of Medical Sciences (IR.SBMU.RETECH.REC.1397.1216).Written informed consents were taken from all patients' parents before case enrolment.

\section{Consent for publication}

This study was retrospective and ethic committee approved anonymous publication of data.

\section{Competing interests}

The authors declare that they have no competing interests.

\section{Author details}

${ }^{1}$ Departments of pediatrics, Loghman Hakim Hospital, School of Medicine, Shahid Beheshti University of Medical Sciences, South Kargar St, Makhsos St" Tehran, Iran. ${ }^{2}$ Department of Clinical Toxicology, School of Medicine, Shahid Beheshti University of Medical Sciences, Tehran, Iran. ${ }^{3}$ Social Determinants of Health Research Center, Shahid Beheshti University of Medical Sciences, Tehran, Iran. ${ }^{4}$ Infectious and Tropical Diseases Research Center, Shahid Beheshti University of Medical Sciences, Tehran, Iran. ${ }^{5}$ Kish Institute of Science and Technology, Tehran, Iran.

Received: 20 April 2020 Accepted: 6 July 2020

Published online: 20 July 2020

\section{References}

1. Gilchrest BA. Sun exposure and vitamin D sufficiency. Am J Clin Nutr. 2008; 88(2):570S-7S

2. Moran DS, McClung JP, Kohen T, Lieberman HR. Vitamin D and physical performance. Sports Med. 2013;43(7):601-11.

3. Calvo M, Babu U, Garthoff L, Woods T, Dreher M, Hill G, et al. Vitamin D 2 from light-exposed edible mushrooms is safe, bioavailable and effectively supports bone growth in rats. Osteoporos Int. 2013;24(1):197-207.

4. Jones G. Pharmacokinetics of vitamin D toxicity. Am J Clin Nutr. 2008;88(2): 582S-6S.

5. Bischoff-Ferrari HA, Shao A, Dawson-Hughes B, Hathcock J, Giovannucci E, Willett WC. Benefit-risk assessment of vitamin D supplementation. Osteoporos Int. 2010;21(7):1121-32. 
6. Holick MF. The vitamin D deficiency pandemic: a forgotten hormone important for health. Public Health Rev. 2010;32(1):267.

7. Su Z, Narla SN, Zhu Y. 25-Hydroxyvitamin D: analysis and clinical application. Clin Chim Acta. 2014:433:200-5.

8. Lips P, van Schoor NM, Bravenboer N. Vitamin D-related disorders. Primer on the metabolic bone diseases and disorders of mineral metabolism. 2013: 613-23

9. Makariou S, Liberopoulos EN, Elisaf M, Challa A. Novel roles of vitamin D in disease: what is new in 2011? Eur J Intern Med. 2011;22(4):355-62.

10. Raubenheimer $E$, Noffke C. Vitamin D and health: a historical overview. SA Orthop J. 2011;10(2):39-43.

11. Zhang R, Naughton DP. Vitamin D in health and disease: current perspectives. Nutr J. 2010;9(1):65.

12. Zittermann A, Schleithoff SS, Koerfer R. Vitamin D insufficiency in congestive heart failure: why and what to do about it? Heart Fail Rev. 2006;11(1):25.

13. Dawodu A, Dawson K, Amirlak I, Kochiyil J, Agarwal M, Badrinath P. Diet, clothing, sunshine exposure and micronutrient status of Arab infants and young children. Ann Trop Paediatr. 2001;21(1):39-44.

14. Shahla A, Charehsaz S, Talebi R, Omrani M. Vitamin D deficiency in young females with musculoskeletal complaints in Urmia, northwest of Iran. Iran J Med Sci. 2005;30(2)

15. Heshmat R, Mohammad K, Majdzadeh S, Forouzanfar M, Bahrami A, Ranjbar Omrani G. Vitamin D deficiency in Iran: A multi-center study among different urban areas. Iran J Public Health. 2008;37(1):72-8.

16. Bell D, Crooke M, Hay N, Glendenning P. Prolonged vitamin D intoxication: presentation, pathogenesis and progress. Intern Med J. 2013;43(10):1148-50.

17. Razzaque MS. Can adverse effects of excessive vitamin D supplementation occur without developing hypervitaminosis D? J Steroid Biochem Mol Biol. 2018;180:81-6.

18. Lowe H, Cusano NE, Binkley N, Blaner WS, Bilezikian JP. Vitamin D toxicity due to a commonly available "over the counter" remedy from the Dominican Republic. J Clin Endocrinol Metab. 2011;96(2):291-5.

19. Kaur $P$, Mishra SK, Mithal A. Vitamin D toxicity resulting from overzealous correction of vitamin D deficiency. Clin Endocrinol. 2015;83(3):327-31.

20. Vogiatzi MG, Jacobson-Dickman E, DeBoer MD, Drugs, Society TCoTPE. Vitamin D supplementation and risk of toxicity in pediatrics: a review of current literature. J Clin Endocrinol Metab. 2014;99(4):1132-41.

21. Anık A, Çatlı G, Abacı A, Dizdarer C, Böber E. Acute vitamin D intoxication possibly due to faulty production of a multivitamin preparation. J Clin Res Pediatr Endocrinol. 2013;5(2):136.

22. Araki T, Holick MF, Alfonso BD, Charlap E, Romero CM, Rizk D, et al. Vitamin $D$ intoxication with severe hypercalcemia due to manufacturing and labeling errors of two dietary supplements made in the United States. J Clin Endocrinol Metab. 2011;96(12):3603-8.

23. Kaptein S, Risselada AJ, Boerma EC, Egbers PH, Nieboer P. Life-threatening complications of vitamin D intoxication due to over-the-counter supplements. Clin Toxicol. 2010;48(5):460-2.

24. Kara C, Gunindi F, Ustyol A, Aydin M. Vitamin D intoxication due to an erroneously manufactured dietary supplement in seven children. Pediatrics. 2014;133(1):e240-e4.

25. Ketha $H$, Wadams $H$, Lteif $A$, Singh RJ. latrogenic vitamin D toxicity in an infant-a case report and review of literature. J Steroid Biochem Mol Biol. 2015;148:14-8.

26. Monk RD, Bushinsky DA. Making sense of the latest advice on vitamin D therapy. J Am Soc Nephrol. 2011;22(6):994-8.

27. Hawkes CP, Schnellbacher S, Singh RJ, Levine MA. 25-hydroxyvitamin D can interfere with a common assay for 1, 25-dihydroxyvitamin D in vitamin D intoxication. J Clin Endocrinol Metab. 2015;100(8):2883-9.

28. Radlović $N$, Leković $Z$, Ristić $D$, Radlović $V$, Đuričić $G$, Dimitrijević $A$, et al. Case report of acute vitamin D intoxication in an infant. Srp Arh Celok Lek 2014;142(11-12):736-9.

29. Holick MF. Vitamin D and health: evolution, biologic functions, and recommended dietary intakes for vitamin D. Vitamin D: Springer; 2010. pp. 3-33.

30. Is I. The prophylactic requirement and the toxicity of vitamin D. Pediatrics. 1963.

31. Kołodziejczyk A, Borszewska-Kornacka MK, Seliga-Siwecka J. MOnitored supplementation of VItamin D in preterm infants (MOSVID trial): study protocol for a randomised controlled trial. Trials. 2017;18(1):424.

32. Cusano NE, Thys-Jacobs S, Bilezikian JP. Hypercalcemia due to vitamin D toxicity. Vitamin D: Elsevier; 2018. pp. 507-26.
33. Feige J, Salmhofer H, Hecker C, Kunz AB, Franzen M, Moré E, et al. Lifethreatening vitamin $D$ intoxication due to intake of ultra-high doses in multiple sclerosis: A note of caution. Mult Scler J. 2019;25(9):1326-8.

34. DeLuca HF, Prahl JM, Plum LA. 1, 25-Dihydroxyvitamin D is not responsible for toxicity caused by vitamin D or 25-hydroxyvitamin D. Arch Biochem Biophys. 2011;505(2):226-30.

35. Elisa Kit Vit D. https://bit.ly/2ZiMehU. Accessed 12 July 2020.

36. Marcinowska-Suchowierska E, Kupisz-Urbańska M, Łukaszkiewicz J, Płudowski P, Jones G. Vitamin D toxicity-a clinical perspective. Front Endocrinol. 2018; 9:550.

37. Jazayeri M, Moradi Y, Rasti A, Nakhjavani M, Kamali M, Baradaran HR. Prevalence of vitamin D deficiency in healthy Iranian children: A systematic review and meta-analysis. Med J Islam Repub Iran. 2018;32:83.

38. Amiri M. Evaluation of Serum Vitamin D Levels in Foster's Children Care Center. J Pediatric Health Nutr. 2019;1(2):1.

39. Thanacoody R, Anderson M. Epidemiology of poisoning. Medicine. 2020.

40. Potdar SM, Junagade SV, Kumavat V, Panot JN. Clinicalprofile of poisoning in children. Int J Sci Res. 2019;8(9).

41. Barrueto F, Wang-Flores HH, Howland MA, Hoffman RS, Nelson LS. Acute vitamin D intoxication in a child. Pediatrics. 2005:116(3):e453-6.

42. Conti G, Chirico V, Lacquaniti A, Silipigni L, Fede C, Vitale A, et al. Vitamin D intoxication in two brothers: be careful with dietary supplements. J Pediatr Endocrinol Metab. 2014;27(7-8):763-7.

43. Gerspach C, Bateman S, Sherding R, Chew D, Besier A, Grieves J, et al. Acute renal failure and anuria associated with vitamin $D$ intoxication in two alpaca Vicugna pacos) cria. J Vet Intern Med. 2010;24(2):443-9.

44. Guerra V, Vieira Neto OM, Laurindo AF, Paula FJAd, Moysés Neto M. Hypercalcemia and renal function impairment associated with vitamin D toxicity: case report. Braz J Nephrol. 2016;38(4):466-9.

45. Pandita KK, Razdan S, Kudyar RP, Beigh A, Kuchay S, Banday T. "Excess gooD can be Dangerous". A case series of iatrogenic symptomatic hypercalcemia due to hypervitaminosis D. Clin Cases Miner Bone Metab. 2012;9(2):118.

46. Wani M, Wani I, Banday K, Ashraf M. The other side of vitamin D therapy: a case series of acute kidney injury due to malpractice-related vitamin D intoxication. Clin Nephrol. 2016;86(5):236.

47. Marwaha R, Khadgawat R, Tandon N, Kanwar R, Narang A, Sastry A, et al. Reference intervals of serum calcium, ionized calcium, phosphate and alkaline phosphatase in healthy Indian school children and adolescents. Clin Biochem. 2010;43(15):1216-9.

48. Sturgeon CM, Viljoen A. Analytical error and interference in immunoassay: minimizing risk. Ann Clin Biochem. 2011;48(5):418-32.

49. He C-S, Gleeson M, Fraser WD. Measurement of circulating 25-hydroxy vitamin d using three commercial enzyme-linked immunosorbent assay kits with comparison to liquid chromatography: tandem mass spectrometry method. ISRN Nutr. 2013;2013.

50. Mohamadzadeh A, Sayedi SJ, Rezaei M. A case report of hypervitaminosis D in 2 months old infant. Iran J Neonatol IJN. 2013;4(2):38-40.

51. Spiller H, Good T, Spiller N, Aleguas A. Vitamin D exposures reported to US poison centers 2000-2014: temporal trends and outcomes. Hum Exp Toxicol. 2016;35(5):457-61.

52. Alshahrani F, Aljohani N. Vitamin D: deficiency, sufficiency and toxicity. Nutrients. 2013;5(9):3605-16

53. Norman AW, Bouillon R. Vitamin D nutritional policy needs a vision for the future. Exp Biol Med. 2010;235(9):1034-45.

54. Ozer I, Ozcetin M, Yilmaz R. Case Report The Importance of Dietary Therapy in Acute Vitamin D Intoxication. HK J Paediatr (new series). 2011;16(3):180-3.

\section{Publisher's Note}

Springer Nature remains neutral with regard to jurisdictional claims in published maps and institutional affiliations. 